\title{
Site-Specific Aquifer Characterization and Identification of Potential Groundwater Areas in Pakistan
}

\author{
Hafiz Umar Farid ${ }^{1 *}$, Zahid Mahmood-Khan', Akhtar Ali', \\ Muhammad Mubeen ${ }^{2}$, Muhammad Naveed Anjum ${ }^{3}$
}

\begin{abstract}
${ }^{1}$ Department of Agricultural Engineering, Bahauddin Zakariya University, Multan-Pakistan
${ }^{2}$ Department of Environmental Sciences, COMSATS Institute of Information Technology, Vehari, Pakistan ${ }^{3}$ Division of Hydrology Water-Land Resources in Cold and Arid Regions, Cold and Arid Region Environmental and Engineering Institute, Chinese Academy of Sciences, Lanzhou, Gansu 730000, China
\end{abstract}

Received: 5 June 2016

Accepted: 12 August 2016

\begin{abstract}
Detailed knowledge about site-specific aquifer characteristics, subsurface lithology, and groundwater potential can help to determine the depth and location of fresh groundwater quality. The present research study was carried out by conducting 80 vertical electrical sounding surveys (VESs) in Rahim Yar Khan District (RYK), Punjab, Pakistan to distinguish the fresh groundwater aquifer from saline groundwater and to evaluate the aquifer protective capacity (APC) of overburden. 1XID software (Interpex, USA) was used to accomplish the interpretation of VES data. The VES interpreted data was used to prepare spatial distribution maps of aquifer apparent resistivity (AR), layer thickness, longitudinal conductance (LC), and transverse resistance (TR) for the second, third, and fourth subsurface layers using ArcGIS 10.1. The results showed that the greater part of the study area (65\%) had four subsurface geo-electric layers. The spatial distribution maps for AR showed that the fresh groundwater quality was present on the northwestern and northeastern sides of the study area for all the layers. The results also indicated that the APC of overburden increased with the increase of depth from the ground surface. Layer 4 with thickness of $57.09 \mathrm{~m}$ showed good APC in the northern and central parts with LC values of $>0.7$ mhos. Similarly, the higher values of TR showed higher yield potential in the north-eastern part as compared to the southern part. Overall analysis indicated that the spatial distribution maps of AR, layer thickness, LC, and TR should be helpful for future groundwater development in terms of quality and quantity.
\end{abstract}

Keywords: VES, apparent resistivity, APC, groundwater potential zones, groundwater development

*e-mail: farid_vjr@yahoo.com, hufarid@bzu.edu.pk 


\section{Introduction}

The agricultural sector is considered one of the most important components of Pakistan's economy. Its current contribution to gross domestic product (GDP) is about $20.9 \%$ [1]. Moreover, the agriculture sector creates prolific employment opportunities for $45 \%$ of the country's labor force and also provides direct or indirect livelihood to $67 \%$ of the rural population. It has been reported that the present population of Pakistan is more than 180 million, which is projected to rise to 246 million by 2025 [2-3]. At the same time, the need to meet the growing demands of food for the increasing population will require and increase in crop production, whereas crop production mainly depends upon availability of irrigation water. However, Pakistan has the world's largest gravity flow canal irrigation system carrying 82 MAF canal water, but due to poor management its efficiency is very low (in the range of about $40 \%$ ) [45]. So water availability is becoming the most important factor for sustaining the agricultural sector in Pakistan.

Currently, irrigation water supplies are about $30 \%$ lower than those required for the present cropping intensity $[3,6]$, and canal water supplies are highly inadequate, variable, and unreliable. On the other hand, most of the area in the Indus River Basin of Pakistan receives average annual rainfall of $<250 \mathrm{~mm}$ (showing the arid nature of the region), which is not sufficient to grow a single crop [78]. This situation has led farmers to exploit groundwater resources to increase their surface water supplies, to overcome canal water scarcity, and to get more control over irrigation water supplies. On average, every fourth farming family has its own tube wells, and a large proportion of non-owners purchase groundwater through local fragmented groundwater markets [9-10]. It has been reported that more than 50\% of Pakistan's irrigated lands are now served by groundwater wells [11].

More irrigated area by the groundwater means more exploitation of groundwater. As a result, groundwater is gradually turning saline along with increasing water table depth. This increase in depth has increased the pumping cost of groundwater [12]. Similarly, irrigation with brackish groundwater may cause an excessive accumulation of salts in the soil profile. Latif and Ahmed [13] reported that more than $60 \%$ of groundwater pumped by farmers for irrigation purposes has brackish groundwater quality. One of the major reasons for pumping brackish/ saline water is the installation of tube wells by a large number of farmers without any prior investigation about groundwater quality and quantity [14-16]. Moreover, rapid urbanization and industrialization have increased solid waste and wastewater generation. So, disposal of solid waste, sewage, urban runoff, agricultural chemicals, and polluted surface water are the major contributors to deteriorate the quality of groundwater resources. Of course landfill sites generally seem adequate for the urban areas to handle garbage issues, but groundwater is a major threat from these sites due to unplanned activities. So, it is suspected that leachate goes down through the soil and is mixed with groundwater because there is no proper mechanism to collect leachate and protect the aquifer. The need, therefore, arises to evaluate the aquifer protective capacity (APC, which is defined as the capacity of the aquifer material to underline and filter percolating surface polluted water into the aquifer) of the overburden material in the area in order to establish the level of safety of the hydrogeologic system [17-19].

Therefore, a systematic and scientific approach to the problem is essential in order to overcome these problems. In such circumstances, the geophysical methods have been successfully used in groundwater studies since they are usually noninvasive and relatively cheap [2021]. Geophysical methods, especially vertical electrical soundings (VES), have been used successfully for investigating groundwater quality and APC in different lithological settings [19-23]. The VES survey technique also has been used effectively for the study of groundwater conditions and to asses the APC of subsurface geoelctrical layers [24-25]. This VES survey data can be employed to develop spatial distribution maps of groundwater quality, layer thickness, APC, and water-bearing formation potential [26-27]. Such maps can provide information to farmers about the subsurface layering and groundwater quality for installation of tube wells at suitable depths below the ground surface. These can also be used for better management of groundwater resources for its future development and to improve the productivity of agricultural activities in the area.

Keeping this in view, the present research study was carried out to provide useful information to the farmers of Rahim Yar Khan (RYK) in Southern Punjab, Pakistan, to distinguish the fresh groundwater aquifer from saline groundwater. Additionally, the APC of overburden was determined and mapped using VES data in geographic information system (GIS).

\section{Materials and Methods}

\section{Location of Study Area}

The experimental study was conducted in Rahim Yar Khan (RYK) District in Pakistan's southern Punjab Province (Fig. 1). The district is located between latitude $27.66^{\circ}$ to $29.27^{\circ}$ and longitude $69.05^{\circ}$ to $71.02^{\circ}$. It has three main physical regions: 1) the riverside area (on the southern side of the Indus River), 2) the canal irrigated area in the southern part of the district, and 3) the desert area in the southeastern part. Cotton, sugarcane, and wheat are the major crops. The climate of the district is hot and dry in summer and cold and dry in winter. The average annual rainfall is about $165 \mathrm{~mm}$ [28].

\section{Data Collection and Interpretation}

A total of 80 VESs were conducted within the study area in collaboration with the Agricultural Engineering Workshops (Field Wing) District RYK Punjab, Pakistan because the instrument is owned by this department. 

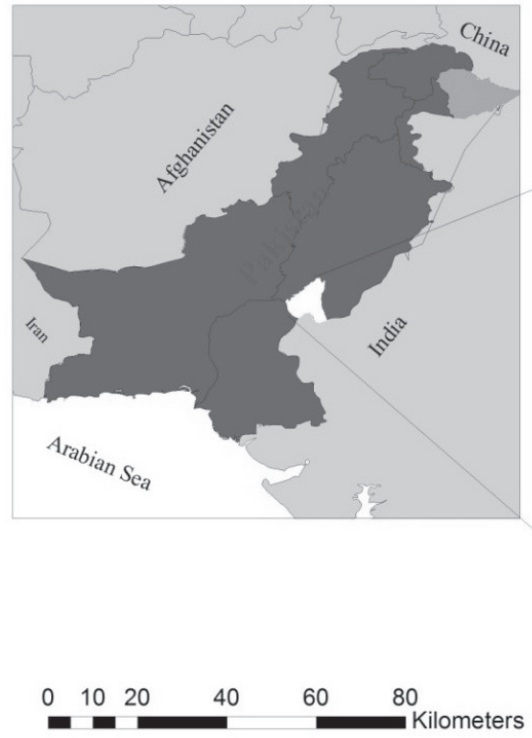

Fig. 1. Study area in RYK District of Punjab Province, Pakistan.

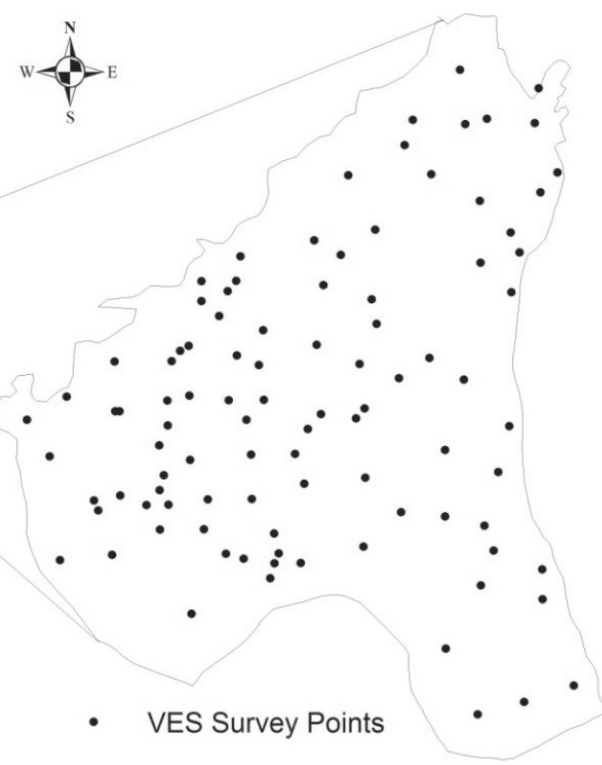

A resistivity meter (ABEM SAS 4000 Tetrameter) was used to determine the apparent resistivity (AR) data with Schlumberger electrode configuration having maximum current electrode separation $(\mathrm{AB} / 2)$ of $180 \mathrm{~m}$. A series of measurements for earth resistivity were made by increasing the electrode spacing in each successive step around a fixed point for all the VES surveys (almost 25 values were obtained for each of $80 \mathrm{VESs}$ ). Measured earth resistivity $(R)$ was multiplied with respective geometric constant $(\mathrm{K})$ to determine the AR as obtained by many other researchers [14-16, 29-30]. The mean, maximum, and minimum AR values calculated from field VES data of 80 locations are given in Table 1. The mean AR values were obtained in the range of $0.97-113.04$ Ohm-m. The maximum AR value of $2067.84 \mathrm{Ohm}-\mathrm{m}$ was determined at VES- 66 position having latitude of $28.21^{\circ}$ and longitude of $70.20^{\circ}$. Similarly, the minimum value of -1889.43 Ohm-m was obtained at the VES-12 position.

1-D inversion computer software (1XID, Interpex, USA) was used to interpret VES data. The software has the ability to generalize the resistivity data in the form of a subsurface layer model by fitting the observed field data with least root mean squire error (RMSE) between the measured and predicted resistivity data. The software dialog box has dynamic columns and rows to make the data entry more convenient. Similarly, toll bar buttons are provided for the most used menu commands, including new sounding, open and import data, save, display selection, zoom status, un-zoom, edit data, forward, equivalence and inverse calculations, and determination of layered and smooth models. The methods of iteration in the software were performed until the fitting error between the measured and the predicted field data became minimum and constant $[14,18]$. Two boreholes were drilled to a depth of $80 \mathrm{~m}$ below the ground surface to verify the VES results [15]. About 35 soil and water samples were collected at a 3-5 m interval from each drilled borehole. Soil textural analysis and water chemical analysis were carried out in the Soil and Water Testing Laboratory, Punjab Agriculture Department, RYK. The borehole data were used to prepare the two well-logs that further validated the interpreted VES results. From the interpretation of VES data, the Dar Zarrouk Parameters (the combination thickness and resistivity into a single variable) were computed to evaluate the aquifer properties and protection capacity of groundwater resources [3132]. The Dar Zarrouk Parrameters consist of longitudinal conductance (LC) and transverse resistance (TR). For a homogeneous, isotropic, and horizontal layer, LC (mho) is expressed as $\mathrm{LC}_{i}=\mathrm{h}_{i} / \mathrm{AR}_{i}$ and $\mathrm{TR}$ is expressed as $\mathrm{TR}_{i}=\mathrm{AR}\left(\mathrm{h}_{i}\right)$, where $\mathrm{h}_{i}$ is the thickness in meters of the ith layer, and $\mathrm{AR}_{i}$ the apparent resistivity in Ohm-meters of the ith layer. Similarly, the LC has been used to evaluate the APC of the aquifer overburden [18]. The total dissolved solids (TDS) were also determined from water chemical analysis, and the relationship between TDS and AR was developed to examine groundwater quality.

\section{Preparation of Spatial Distribution Maps}

Spatial distribution maps for aquifer AR, layer thickness, LC, and TR were prepared for the second, third, and fourth layers using ArcGIS 10.1. The spatial distribution maps for the first layer were not prepared because the first layer almost contained the unsaturated strata. The VES locations were obtained using a GPS receiver. The ordinary kriging from the ArcGIS spatial analyst tool was used to obtain the spatial distribution of aquifer parameters such as aquifer AR, layer thickness, LC, and TR over the study area. Kriging is most suitable interpolation technique and has many advantages over the others as reported in literature. Such an approach has been recommended and used by many other researchers [33-36]. Kumar and Remadevi [37] compared the 
Table 1. Mean, maximum, and minimum apparent resistivity (AR) values obtained using an ABEM SAS 4000 Tetrameter resistivity meter.

\begin{tabular}{|c|c|c|c|c|c|c|c|c|c|c|c|}
\hline \multirow{2}{*}{$\begin{array}{c}\text { VES } \\
\text { number }\end{array}$} & \multirow[t]{2}{*}{$\mathrm{E}$} & \multirow[t]{2}{*}{$\mathrm{N}$} & \multicolumn{3}{|c|}{ Apparent resistivity (Ohm-m) } & \multirow{2}{*}{$\begin{array}{l}\text { VES } \\
\text { number }\end{array}$} & \multirow[t]{2}{*}{$\mathrm{E}$} & \multirow[t]{2}{*}{$\mathrm{N}$} & \multicolumn{3}{|c|}{$\begin{array}{l}\text { Apparent resistivity } \\
(\mathrm{Ohm}-\mathrm{m})\end{array}$} \\
\hline & & & Mean & Max & Min & & & & Mean & Max & Min \\
\hline 1 & 70.29 & 28.39 & 9.18 & 56.85 & -3.59 & 41 & 70.37 & 28.15 & 4.44 & 19.23 & 0.65 \\
\hline 2 & 70.22 & 28.44 & 9.43 & 23.86 & 0.01 & 42 & 70.43 & 28.33 & 7.44 & 26.02 & 1.25 \\
\hline 3 & 70.42 & 28.32 & 113.04 & 213.11 & 51.85 & 43 & 70.02 & 28.09 & 30.68 & 47.77 & 11.81 \\
\hline 4 & 70.42 & 28.32 & 1.51 & 6.59 & 0.00 & 44 & 70.30 & 28.44 & 36.83 & 83.23 & 9.80 \\
\hline 5 & 70.81 & 29.21 & 66.75 & 545.24 & 0.00 & 45 & 70.43 & 28.42 & 2.19 & 44.26 & -41.19 \\
\hline 6 & 70.34 & 28.51 & 46.12 & 80.94 & 0.00 & 46 & 70.94 & 28.12 & 61.82 & 72.06 & 49.18 \\
\hline 7 & 70.36 & 28.34 & 40.17 & 62.78 & 17.37 & 47 & 70.99 & 28.84 & 58.55 & 86.58 & 22.08 \\
\hline 8 & 70.43 & 28.35 & 22.90 & 119.91 & 5.58 & 48 & 70.29 & 28.42 & 19.07 & 26.86 & 12.27 \\
\hline 9 & 70.43 & 28.35 & 12.88 & 31.38 & 1.15 & 49 & 70.81 & 29.09 & 41.16 & 65.02 & 47.95 \\
\hline 10 & 70.43 & 28.35 & 21.36 & 62.89 & 3.02 & 50 & 70.01 & 28.41 & 27.98 & 48.50 & 11.90 \\
\hline 11 & 70.43 & 28.35 & 85.14 & 635.97 & 7.25 & 51 & 70.32 & 28.40 & 1.51 & 2.61 & 0.27 \\
\hline 12 & 70.51 & 28.63 & 95.41 & $1,297.06$ & $-1,889.43$ & 52 & 70.32 & 28.40 & 26.55 & 42.34 & 10.14 \\
\hline 13 & 70.51 & 28.63 & 5.15 & 47.63 & -0.77 & 53 & 70.16 & 28.25 & 3.72 & 23.60 & 1.25 \\
\hline 14 & 70.51 & 28.63 & 85.14 & 635.97 & 7.25 & 54 & 70.27 & 28.37 & 13.42 & 118.31 & -5.77 \\
\hline 15 & 70.35 & 28.29 & 20.97 & 44.73 & 0.82 & 55 & 70.27 & 28.37 & 10.56 & 25.28 & 5.88 \\
\hline 16 & 70.35 & 28.29 & 6.08 & 95.57 & 0.83 & 56 & 70.94 & 28.12 & 39.65 & 51.84 & 19.23 \\
\hline 17 & 70.81 & 27.76 & 15.41 & 20.74 & 11.28 & 57 & 70.08 & 28.92 & 23.46 & 39.67 & 12.12 \\
\hline 18 & 70.58 & 28.44 & 2.26 & 10.13 & -2.51 & 58 & 70.81 & 27.79 & 5.28 & 9.59 & 4.44 \\
\hline 19 & 70.67 & 28.47 & 28.91 & 115.70 & 1.08 & 59 & 70.06 & 27.89 & 5.93 & 8.02 & 4.22 \\
\hline 20 & 70.85 & 29.00 & 39.48 & 61.02 & 19.63 & 60 & 70.32 & 28.40 & 30.18 & 34.92 & 20.86 \\
\hline 21 & 70.27 & 28.22 & 12.55 & 162.17 & 0.00 & 61 & 70.34 & 28.51 & 9.31 & 21.01 & 0.68 \\
\hline 22 & 70.63 & 28.48 & 7.92 & 15.75 & 2.62 & 62 & 70.27 & 28.42 & 6.71 & 11.84 & 2.60 \\
\hline 23 & 70.63 & 28.48 & 9.42 & 41.50 & 1.83 & 63 & 70.66 & 28.65 & 27.40 & 81.97 & 6.49 \\
\hline 24 & 70.25 & 28.20 & 6.34 & 53.31 & -13.97 & 64 & 70.10 & 27.86 & 35.04 & 52.22 & 12.90 \\
\hline 25 & 70.25 & 28.20 & 16.31 & 31.53 & 3.41 & 65 & 70.15 & 27.86 & 90.90 & 190.38 & 65.55 \\
\hline 26 & 70.67 & 28.47 & 8.93 & 22.91 & 1.43 & 66 & 70.20 & 28.21 & 54.07 & $2,067.84$ & -188.40 \\
\hline 27 & 70.67 & 28.47 & 4.58 & 22.91 & 0.68 & 67 & 70.81 & 29.21 & 51.85 & 173.34 & 0.00 \\
\hline 28 & 70.67 & 28.47 & 11.06 & 22.91 & 2.74 & 68 & 70.20 & 28.21 & 63.47 & $1,666.68$ & -20.30 \\
\hline 29 & 70.67 & 28.47 & 25.43 & 56.63 & 7.30 & 69 & 70.20 & 28.21 & 28.20 & 111.91 & -31.23 \\
\hline 30 & 70.02 & 28.12 & 16.25 & 35.99 & 1.30 & 70 & 70.51 & 28.81 & 52.85 & 144.88 & 28.00 \\
\hline 31 & 70.02 & 28.12 & 8.23 & 16.16 & 0.69 & 71 & 71.01 & 27.70 & 5.18 & 21.01 & 0.68 \\
\hline 32 & 70.98 & 28.98 & 17.60 & 57.15 & 2.52 & 72 & 71.03 & 28.88 & 9.31 & 11.84 & 2.60 \\
\hline 33 & 70.98 & 28.08 & 7.79 & 16.81 & 0.76 & 73 & 71.06 & 27.84 & 6.71 & 9.49 & 3.45 \\
\hline 34 & 70.99 & 29.05 & 1.18 & 2.03 & 0.01 & 74 & 71.11 & 27.81 & 7.40 & 9.22 & 2.32 \\
\hline 35 & 70.13 & 28.36 & 40.47 & 56.18 & 15.29 & 75 & 69.75 & 28.44 & 15.04 & 19.23 & 0.67 \\
\hline 36 & 70.08 & 28.34 & 42.55 & 103.09 & 14.35 & 76 & 69.80 & 28.16 & 20.90 & 27.61 & 1.74 \\
\hline 37 & 70.08 & 28.34 & 38.98 & 66.19 & 18.25 & 77 & 69.86 & 28.32 & 17.07 & 32.91 & 0.88 \\
\hline 38 & 70.14 & 28.14 & 4.19 & 27.45 & -3.11 & 78 & 69.90 & 28.44 & 21.85 & 26.81 & 1.74 \\
\hline 39 & 70.02 & 28.12 & 14.49 & 54.25 & -4.23 & 79 & 69.96 & 28.23 & 23.47 & 32.13 & 3.32 \\
\hline 40 & 70.02 & 28.09 & 0.97 & 2.11 & 0.67 & 80 & 69.97 & 28.21 & 18.20 & 36.60 & 1.73 \\
\hline
\end{tabular}


Inverse Squire Distance (ISD) and kriging interpolation techniques for the spatial analysis of groundwater levels and reported that the ISD method resulted in higher error as compared to the kriging method. In the present study, the best fit model was selected based on the model fitness to the data using ordinary kriging. The kriged data were grouped using different classification techniques.

The AR kriged data were classified into four groups based on the AR standards for good, marginal, and saline groundwater. It has been reported that AR values $>42$ Ohm-m are considered good-quality groundwater for irrigation, AR values in the range $21-41 \mathrm{Ohm}-\mathrm{m}$ are marginally suitable, and AR values $<21 \mathrm{Ohm}-\mathrm{m}$ are not suitable for irrigation. AR values of $>150 \mathrm{Ohm}-\mathrm{m}$ contain sand and gravel with very good quality groundwater [14, $16,25,38]$. The kriged data for layer thickness were classified into four groups using the manual classification technique. The kriged data for LC were classified into five groups based on the LC standards for poor, weak, moderate, good, and very good protective capacity of the aquifer material as reported by Ojo et al. [19] and Oladapo et al. [39]. Similarly, the kriged data for TR were classified into four groups based on the aquifer potential to water resources and groundwater quality [25].

\section{Results and Discussion}

Table 2 showed the interpreted 1XID (Interpex, USA) model's geo-electrical parameters such as AR, average layer thickness, average depth from the ground surface, average LC, and average TR for the study area. The 28 VES locations had five and 52 VES locations and four subsurface geo-electric layers indicating that the greater part of the area $(65 \%)$ had four subsurface geo-electric layers. Average thicknesses of $6.58,16.68,41.13$, and $57.09 \mathrm{~m}$ were recorded for Layer 1, Layer 2, Layer 3, and Layer 4, respectively. We observed that layer thickness increased from Layer 1 to Layer 4, indicating the greater homogeneity of aquifer material as it moved downward. Similarly, average LC and TR increased from Layer 1 to Layer 4. It was also observed that Layer 4 had greater APC against polluting the aquifer because it has greater average LC as compared to the other three layers [19, 39]. The increasing trend for TR values were also observed from Layer 1 to Layer 4, indicating the potential of the aquifer for groundwater quality and quantity with increasing depth from the ground surface.

\section{Verification of VES model (1XID, Interpex USA)}

Table 3 shows a comparison of the VES model (1XID, Interpex USA) with the borehole data at position VES-1. Layer 1 contained the moist sand and clay that may be a result of the application of irrigation water. The average AR of 936 Ohm-m interpreted for Layer 2 indicated the course sand and gravel with saturated strata of good quality groundwater. Layer 3 was comprised of course sand with alternate layers of clay containing good quality groundwater. Layer 4 exhibited resistivity of 212 Ohm-m and also contained the good quality groundwater (Fig. 2).

Table 2. Summary of interpreted 1XID (Interpex, USA) model geo-electrical parameters.

\begin{tabular}{|c|c|c|c|c|c|c|}
\hline $\begin{array}{l}\text { Layer } \\
\text { number }\end{array}$ & $\begin{array}{c}\text { Apparent resistivity } \\
\text { (AR) } \\
(\mathrm{Ohm}-\mathrm{m})\end{array}$ & $\begin{array}{c}\text { VES } \\
\text { number }\end{array}$ & $\begin{array}{l}\text { Average layer } \\
\text { thickness } \\
(\mathrm{m})\end{array}$ & $\begin{array}{l}\text { Average depth from } \\
\text { ground surface } \\
(\mathrm{m})\end{array}$ & $\begin{array}{c}\text { Average LC } \\
\text { (mhos) }\end{array}$ & $\begin{array}{c}\text { Average TR } \\
\text { Ohm-m² }\end{array}$ \\
\hline \multirow{4}{*}{ Layer1 } & $<21$ & 22 & 7.23 & 7.23 & 1.16 & 62.41 \\
\hline & $22-42$ & 13 & 7.38 & 7.38 & 0.38 & 146.54 \\
\hline & $43-150$ & 28 & 6.61 & 6.60 & 0.12 & 448.79 \\
\hline & $>150$ & 17 & 5.12 & 5.11 & 0.02 & 2020.65 \\
\hline \multirow{4}{*}{ Layer2 } & $<21$ & 22 & 13.36 & 20.59 & 1.84 & 104.59 \\
\hline & $21-42$ & 12 & 30.08 & 37.46 & 1.79 & 516.41 \\
\hline & $43-150$ & 27 & 14.70 & 21.3 & 0.31 & 963.85 \\
\hline & $>150$ & 19 & 8.58 & 13.69 & 0.03 & 3056.47 \\
\hline \multirow{4}{*}{ Layer3 } & $<21$ & 50 & 42.45 & 63.04 & 4.96 & 446.82 \\
\hline & $22-42$ & 9 & 53.78 & 91.24 & 1.68 & 1791.44 \\
\hline & $43-150$ & 13 & 52.65 & 73.95 & 1.08 & 2947.10 \\
\hline & $>150$ & 8 & 15.62 & 29.31 & 0.06 & 4667.34 \\
\hline \multirow{4}{*}{ Layer4 } & $<21$ & 21 & 62.63 & 125.67 & 13.03 & 395.18 \\
\hline & $22-42$ & 8 & 48.54 & 139.78 & 4.12 & 579.16 \\
\hline & $43-150$ & 14 & 65.48 & 139.43 & 1.28 & 3893.43 \\
\hline & $>150$ & 9 & 51.69 & 81.00 & 0.18 & 18451.76 \\
\hline
\end{tabular}


Table 3. Comparison of VES model (1XID, Interpex USA) and lithology at RYK-1.

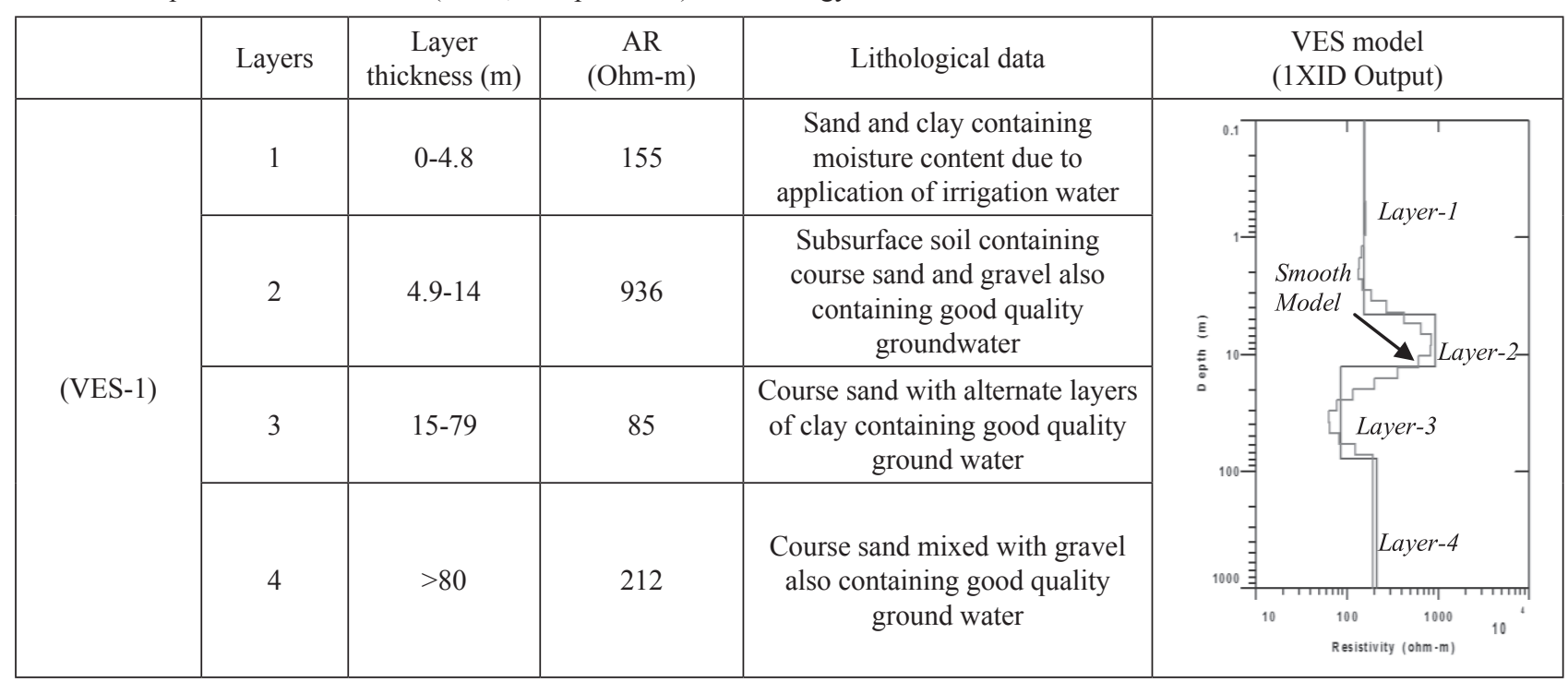

Analysis of the water sample collected from the borehole also showed water electrical conductivity $\left(\mathrm{EC}_{\mathrm{w}}\right)<1.5 \mathrm{dS} / \mathrm{m}$ from 7 to $80 \mathrm{~m}$ below the ground surface. According to the criteria developed by WAPDA [40], groundwater of $\mathrm{EC}_{\mathrm{w}}<1.5 \mathrm{dS} / \mathrm{m}$ is considered fit for irrigation.

VES survey data of the VES-50 position were also compared with the borehole lithology, which showed that Layer 1 from 1-11 $\mathrm{m}$ depth had interpreted AR value of 23 Ohm-m showing the hard clay and surficial soil (Table 4). Layer 2 contained poor quality groundwater as it had AR value of $3 \mathrm{Ohm}-\mathrm{m}$ from 12 to $29 \mathrm{~m}$ depth from the ground surface. We observed very fine sand with alternate layers of clay; it also contained salted water of $\mathrm{EC}_{\mathrm{w}}>3 \mathrm{dS} / \mathrm{m}$ from 12-29 m depth. In Layer 3, deeper than $30 \mathrm{~m}$, the aquifer material of coarse sand mixed with gravel with $\mathrm{AR}$ value of $>42$ Ohm-m showed the presence of good quality groundwater. The overall comparison of VES survey data

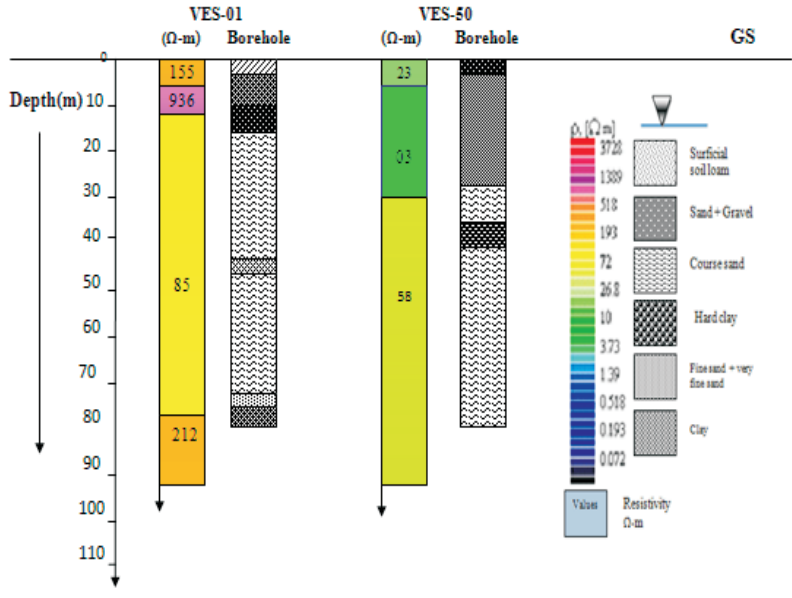

Fig 2. Verification of VES output with the borehole data.

Table 4. Comparison of VES model (1XID, Interpex USA) and lithology at RYK-50.

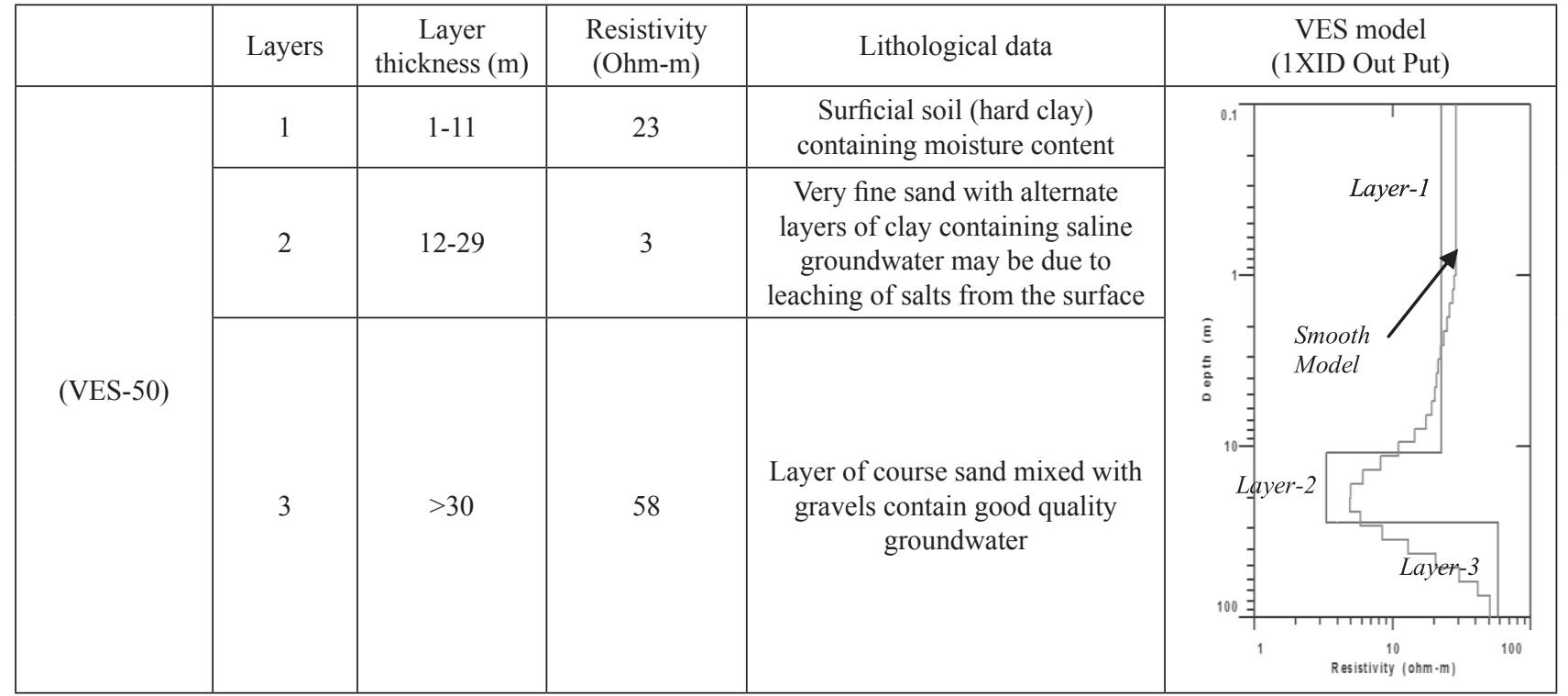



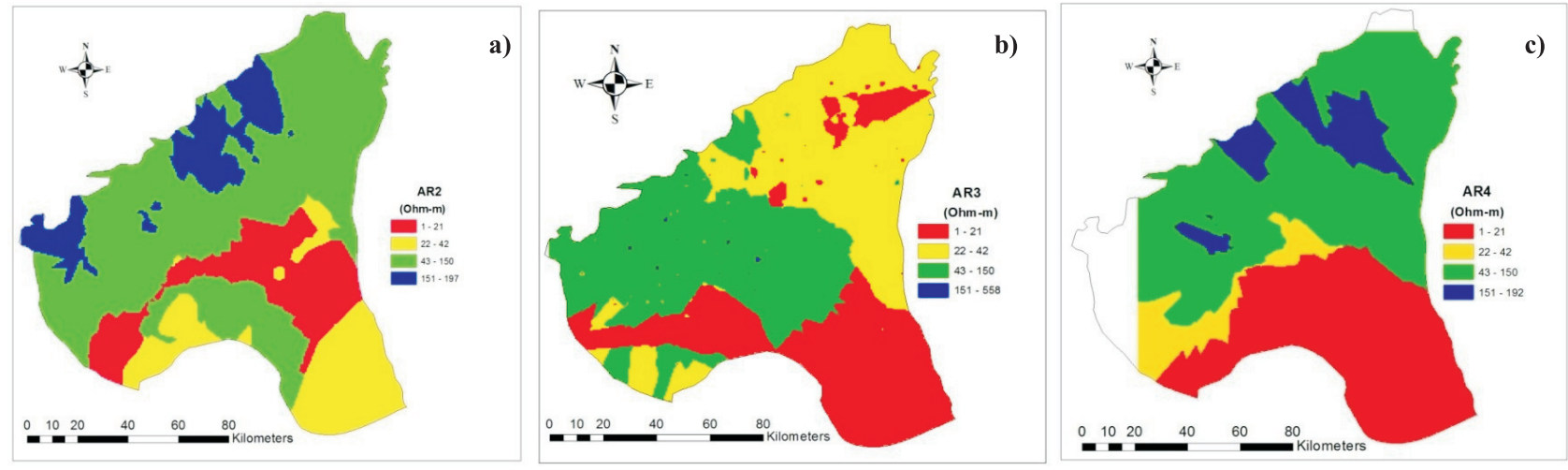

Fig. 3. Apparent Resistivity (AR) of aquifer for subsurface layers for: a) Layer 2, b) Layer 3, c) Layer 4.

interpreted using 1XID (interpex USA) at both sites (VES1 and VES-50) showed close agreement with borehole data, also indicating the effective use of VES survey for groundwater studies (Fig. 2).

\section{Spatial Distribution Maps of Groundwater Quality}

Fig. 3 showed the spatial distribution maps of groundwater quality based on the integration of $\mathrm{AR}$ data for subsurface geo-electric layer (Layer 2 to Layer 4).The fresh water in Layer 2 was found in the northwest and northeast parts of the study area as it had AR values of 43-197 Ohm-m. The marginal quality groundwater predominated in the southeast as well as part in the southern part in the westerly direction with AR values of 22-42 Ohm-m. The brackish quality groundwater with $A R$ value $<21 \mathrm{Ohm}-\mathrm{m}$ was predicted in the central part and running west to southeast of the study area (Fig. 3a). The fresh groundwater quality in Layer 3 was present in the northwest part and marginal quality groundwater was found in the northeast side. The brackish quality groundwater was observed in southeasterly direction (Fig. 3b). Similarly, in Layer 4, fresh groundwater quality was observed in the northeast and northwest parts of the study area. The brackish groundwater quality was found from a south to southeasterly direction (Fig. 3c). The white color in Figure 3c (Layer 4) in the west side and some

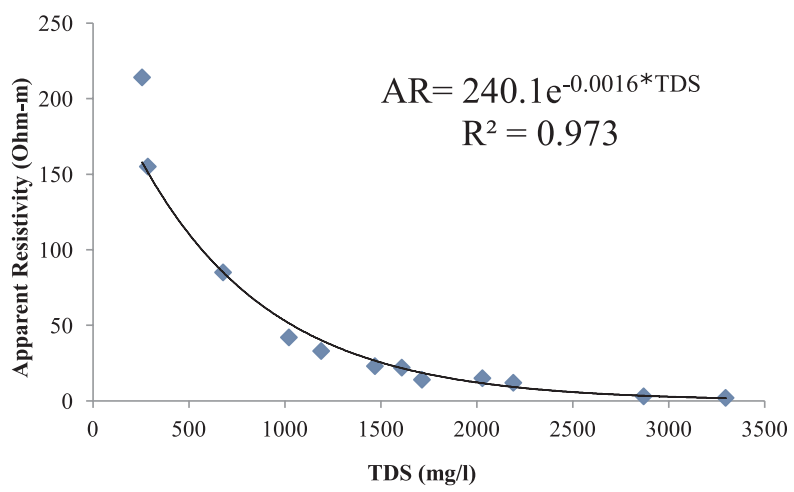

Fig. 4. Relationship between the AR and TDS. portion in the north side showed that Layer 4 was not present there. The results indicated that the greater area of fresh groundwater quality was present in the northwest and northeast side for all the Layers (Figs 3a-c), which may be due to a recharge from the Indus River. It has been reported that the quality of groundwater is better near the river side and the recharge effect was more dominant in the shallow layer [14]. The results also showed that fresh groundwater quality could be pumped from Layer 2 or Layer 4 in the northeast side of the study area instead of Layer 3. The relationship between the total dissolved salts (TDS) and AR showed that the AR value of $>48$ Ohm-m (TDS value $<1,000 \mathrm{mg} / \mathrm{l}$ ) is fit for irrigation purposes, AR value between 23-48 Ohm-m is marginally fit for irrigation, and $<23 \mathrm{Ohm}-\mathrm{m}$ is considered brackish groundwater quality (Fig. 4). The criteria developed for groundwater quality based on the TDS relationship with AR was in close agreement as criteria developed based on the relationship between EC and AR in Rachna and Chaj Doabs [15].

\section{Spatial Distribution Maps of Layer Thickness}

Fig. 5 showed the layer thickness maps of the geoelectric layers (Layers 2, 3, and 4). The thicknesses were observed in the range of 1-22 $\mathrm{m}$ for Layer 2, 1-60 $\mathrm{m}$ for Layer 3, and 1-73 $\mathrm{m}$ for Layer 4 . The increase in layer thickness from Layer 2 to Layer 4 indicated the homogeneity of aquifer material as well as showing the aquifer potential to store water with the increase in depth from the ground surface. Similarly, Daniel et al. [41] reported that the area of thick overburden was expected to yield groundwater in economically useable quantity. The spatial distribution map of layer thickness for Layer 2 showed that maximum thickness of 16-22 $\mathrm{m}$ was found in the eastern part of the study area as well as some part was detected in the western part (Fig. 5a). The spatial distribution map of layer thickness for Layer 3 showed a trend similar to that of Layer 2 (Figs $5 \mathrm{a}$ and $5 \mathrm{~b}$ ). The maximum layer thickness for Layer 4 was examined in the northwest and northeast side and minimum layer thickness was observed in the southeastern part (Fig. 5c). 

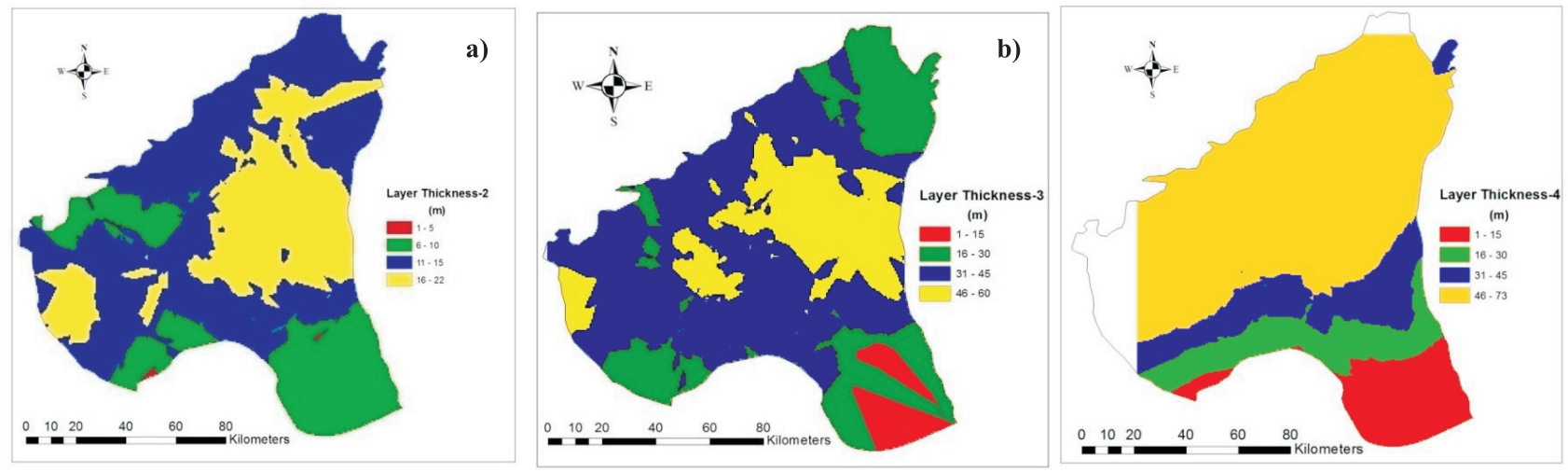

Fig. 5. Map of subsurface layers thickness for: a) Layer 2, b) Layer 3, c) Layer 4.

The results also indicated that layer thickness was higher in the northern part along the Indus River side for all the Layers (Layers 2-4). The higher layer thickness along the riverside may be due to the formation of an aquifer by alluvial deposits brought by the river from the mountains. The higher thickness in that part showed the potential of aquifer formation to store surplus water. It has been reported that the Indus basin aquifer is formed by alluvial sediments and it behaves as homogenous and highly transmissive on a large scale [42-43].

\section{Aquifer Protective Capacity}

The second-order geo-electric parameter, LC, was used to evaluate the aquifer protective capacity (APC) of the geo-electric subsurface layer for the study area (Fig. 6). The spatial distribution map for Layer 2 has an average thickness of $16.68 \mathrm{~m}$, showing that LC values were lower in the northern side and LC values were higher in the central part and again decreased in the southeastern part of the study area. The lower LC values of 0-0.69 mhos in the northern side and southeastern part indicated poor to moderate APC, and the higher LC values of $>0.69$ mhos showed good APC (Fig. 6a). The poor APC in that part may be due to alluvial deposits brought by the river because that part was present along the Indus. It has been reported that pervious material such as sand and gravel have low
LC values resulting from their higher resistivity values as a result of having low APC [19]. The spatial distribution map for Layer 3 with layer thickness of $41.13 \mathrm{~m}$ showed that the maximum areas in the northern and central parts have good APC because it has LC values $>0.69$ mhos [18], while some part in the southeastern side has lower to moderate APC with LC values of 0-0.69 mhos (Fig. 6b). Similarly, the spatial distribution map for Layer 4 with layer thickness of $57.09 \mathrm{~m}$ showed that maximum area in the northern and central parts has good APC as well as some part in the western side having excellent APC with $\mathrm{LC}$ values of $>10$ mhos. Some part in the southeastern side has moderate APC with LC values of 0.2-0.69 mhos (Fig. 6c). The results also indicated that the area of good APC increased with the increase of depth from the ground surface. Similarly, Rahman [44] reported that the APC increased with an increase in water depth because the deeper the water table, the lower the chance of pollutants interacting with the water. It has also been reported that the industrial and domestic effluents discharged into the open drains and fresh water bodies lead to pollution of groundwater into the shallow aquifer [44-45].

\section{Groundwater Potential Zones}

Spatial distribution maps of TR showed the potential of the aquifer for groundwater quality and quantity in the
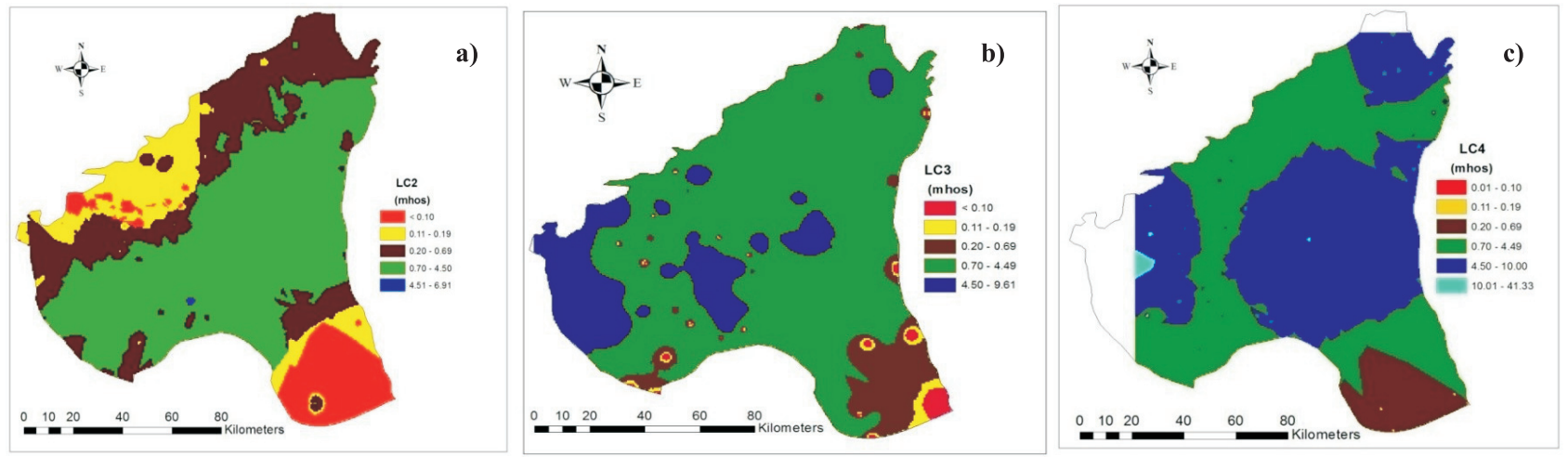

Fig. 6. Longitudinal conductance (LC) map of aquifer for subsurface layers for: a) Layer 2 , b) Layer 3, c) Layer 4. 

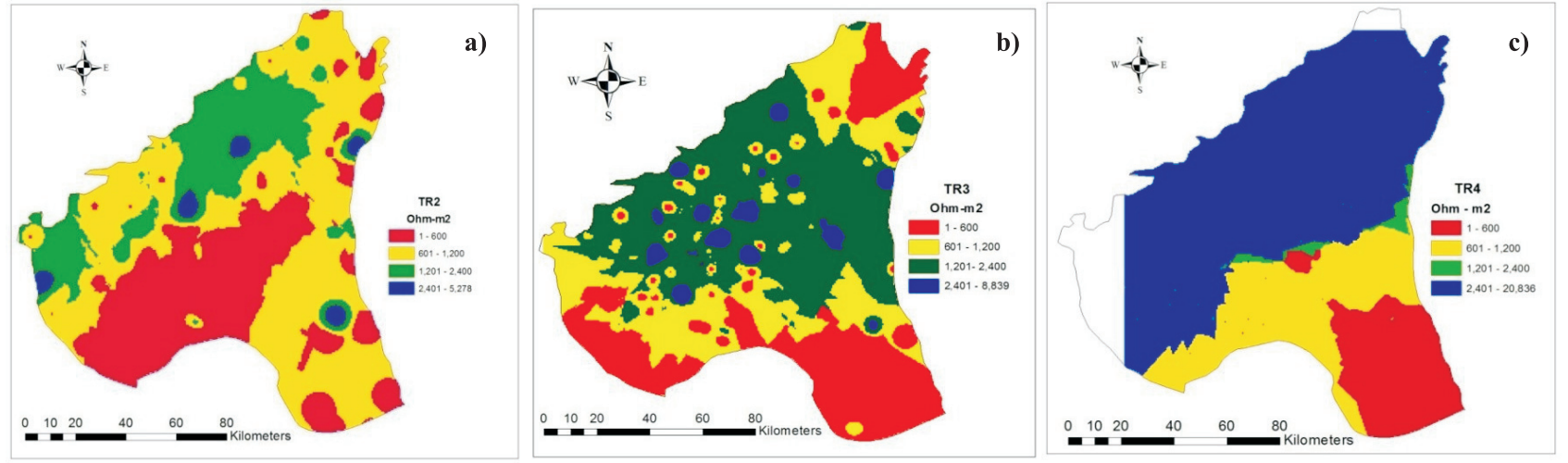

Fig. 7. Transverse resistance (TR) map of aquifer for subsurface layers for:: a) Layer 2 , b) Layer 3, c) Layer 4.

whole study area (Fig. 7). Lashkaripour et al. [25] reported that higher TR (AR multiplied by layer thickness) values constituted higher yield potential and lower TR values constituted lower yield potential. The TR maps for Layer 2 with a layer thickness of $16.68 \mathrm{~m}$ showed that the northeastern and northwestern parts of the study area constituted the higher yield potential; on the other hand, the extreme center of the southwestern part of the study area constituted lower yield potential (Fig. 7a). The TR map for Layer 3 with a thickness of $41.13 \mathrm{~m}$ showed that the area of higher yield potential was running from the northwestern to the central southeastern part of the study area, whereas the lower yield potential area was present at the northeastern corner, the southeast, and some part at the corner of the southwest study area (Fig. 7b). Figure 7c clearly showed that TR values were higher in the northeast and northwestern parts and lower TR values were found in the extreme southeastern part of the study area for Layer 3, which has average thickness of $57.13 \mathrm{~m}$. It was also observed that TR values increased from the northern to southern sides, also showing the increased yield potential from north to south (Fig. 7c). Overall analysis indicated that higher yield potential was observed in the northeastern part along the Indus side as compared to the southern part. The higher yield potential in that part may be due to the recharge of the groundwater from the river. These results also indicated that the best part for future groundwater development was present in the northeastern and northwestern parts of the aquifer because in this part the best quality and quantity of groundwater was found with respect to higher layer thickness and higher AR.

\section{Conclusions}

We drew the following conclusions based on the interpretation of VES data and spatial distribution maps of aquifer parameters:

- The results revealed that VES and spatial distribution maps are effective tools to provide information about the site-specific aquifer characteristics, subsurface lithology, and groundwater potential for exploitation of groundwater in better quality and quantity.
- The average layer thicknesses of $6.58,16.68$, 41.13, and $57.09 \mathrm{~m}$ were recorded for Layers 1-4, respectively. Layer thickness increased from Layer 1 to Layer 4, indicating greater homogeneity of aquifer material as it moved downward.

- The higher average layer thickness for Layer 4 (57.09 $\mathrm{m}$ ) also indicated that the area of thick subsurface formation was expected to have higher groundwater potential aquifer as it has higher TR values.

- The results also indicated that greater fresh-quality groundwater with AR values $>42$ Ohm-m were present in Layers 2 and 4 in the northwest and northeast sides of the study area, which could instead be pumped from Layer 3 .

- The area of good APC increased with the increase of depth from the ground surface, indicating that the aquifers at shallow depth are susceptible to pollution through infiltration of leachate from decomposed refuse dumps that goes down through the soil and mixes with groundwater.

- We observed that the TR values increased from the northern to southern sides, also showing the increase in yield potential from north to south. Overall analysis indicated that the best part for future groundwater development was in the northeastern and northwestern parts of the aquifer (preferably from Layer 4) because in this part the best quality and quantity of groundwater was found with respect to higher layer thickness, good APC, and higher AR.

\section{Acknowledgements}

The authors wish to express their sincere thanks to the Agricultural Engineering Workshops (Field Wing) of District RYK in Punjab, Pakistan for their cooperation and assistance in facilitating the present research study.

\section{References}

1. PES. Pakistan Economic Survey (PES), Ministry of Finance, Government of Pakistan. 23, 2014-15. 
2. ARCHER D., FORSYTHE N., FOWLER H., SHAH S. Sustainability of water resources management in the Indus Basin under changing climatic and socio economic conditions. Hydrology and Earth System Sciences, 14 (8), 1669, 2010.

3. AAMER M., SABIR M.F. Irrigation Water Quality Based on Hydro Chemical Analysis, District Rahim Yar Khan, Pakistan. Journal of Resources Development and Management, 4, 52, 2015.

4. MEMON J.A., THAPA G.B. The Indus irrigation system, natural resources, and community occupational quality in the delta region of Pakistan. Environ. Manage, 47, 173, 2011.

5. PSYB. Pakistan Statistical Year Book 2012, Pakistan Bureau of Statistics, Government of Pakistan, section 1.15: Overall water availability, 2012-13.

6. HAFEEZ M., ULLAH K., HANJRA M. A., BODLA H. U., AHMAD R. N. Surface and Groundwater Contribution in Convening with High Crop Water Demand in Indus Basin. Geophysical Research Abstracts, 12: EGU2010-7664, 2010.

7. QURESHI N.A., ALI Z. Climate change, biodiversity Pakistan's scenario. The Journal of Animal and Plant Sciences, 21 (2 Suppli), 358, 2011.

8. FAO, Irrigation in Southern and Eastern Asia in figures: AQUASTAT Survey - 2011, Food and Agriculture Organization (FAO) of the United Nations Rome, 2012. FAO Water Report 37, 2011.

9. PAKISTAN WATER PARTNERSHIP (PWP). The Framework for Action for Achieving the Pakistan Water Vision 2025. WAPDA: Lahore, Pakistan, 2001.

10. QURESHI A.S., AKHTAR M. Effect of electricity pricing policies on groundwater management in Pakistan. Pakistan Journal of Water Research, 7, 1, 2003.

11. CHAUDHARY M.R., BHUTTA N.M., IQBAL M., SUBHANI K.M. Groundwater resources: use and impact on soil and crops. Paper presented at the Second South Asia Water Forum, 14-16 December, Islamabad, Pakistan, 2002.

12. SHAKIR A.S., REHMAN H., KHAN N.M., QAZI A.U. Impact of canal water shortages on groundwater in the lower Bari doab canal system in Pakistan. Pakistan Journal of Engineering and Applied Sciences 9, 87, 2011.

13. LATIF M., AHMAD M.Z. Groundwater and soil salinity variations in a canal command area in Pakistan. Irrigation and Drainage, 58, 456, 2008.

14. SIKANDAR P., BAKHSH A., ARSHAD M., RANA T. The use of vertical electrical sounding resistivity method for the location of low salinity groundwater for irrigation in Chaj and Rachna Doabs. Environmental Earth Sciences, 60, 1113, 2010.

15. SIKANDAR P., BAKHSH A., ALI T., ARSHAD M. Vertical electrical sounding (VES) resistivity survey technique to explore low salinity groundwater for tubewell installation in Chaj Doab. Journal of Agricultural Research, 48 (4), 547, 2010.

16. 16. FARID H. U., BAKHSH A. Use of vertical electrical sounding (VES) techniques to explore the groundwater potential. Asian Journal of Science and Technology, 6(01): 915-923, 2015.

17. ADENIJI A.E., OMONONA O.V., OBIORA D.N., CHUKUDEBELU J.U. Evaluation of soil corrosivity and aquifer protective capacity using geoelectrical investigation in Bwari basement complex area, Abuja. Journal of Earth System Science, 123 (3), 491, 2014.

18. OKIONGBO K.S., AKPOFURE E. Determination of Aquifer Properties and Groundwater Vulnerability Mapping
Using Geoelectric Method in Yenagoa City and Its Environs in Bayelsa State, South South Nigeria. Journal of Water Resource and Protection, 4, 354, 2012.

19. OJO E.O., ADELOWO A., ABDULKARIM H.M., DAUDA A.K. A Probe into the Corrosivity Level and Aquifer Protective Capacity of the Main Campus of the University of Abuja, Nigeria: Using Resistivity Method. Physics Journal, 1 (2), 172, 2015.

20. STAMPOLIDIS A., TSOURLOS P., SOUPIOS P., MIMIDES T.H., TSOKAS G., VARGEMEZIS G., VAFIDIS A. Integrated geophysical investigation around the brackish spring of Rina, Kalimnos Isl., SW Greece. J Balk GeophysSoc 8 (3), 63, 2005.

21. KALISPERI D., SOUPIOS P., KOULI M., BARSUKOV P., KERSHAW S., COLLINS P., VALLIANATOS F. Coastal aquifer assessment using geophysical methods (TEM, VES), case study: Northern Crete, Greece, $3^{\text {rd }}$ IASME/WSEAS international conference on geology and seismology (GES '09) Cambridge, UK, 24-26 February, 2009.

22. ZOHDY A., EATON G.P., MABEY D.R. Application of surface geophysics to ground-water investigations: techniques of water resources investigations of the United States Geological Survey, chap D1, 2, 116, 1974.

23. SOUPIOS P., KOULI M., VALLIANATOS F., VAFIDIS A., STAVROULAKIS G. Estimation of aquifer parameters from surficial geophysical methods. A case study of Keritis Basin in Crete. J Hydrol 338, 122, 2007.

24. SHANKAR K.R. Affordable water supply and sanitation. In: Groundwater exploration $20^{\text {th }}$ WEDC Conference Colombo, Sri Lanka, 225, 1994.

25. LASHKARIPOUR G.R., GHAFOORI M., DEHGHANI A. Electrical resistivity survey for predicting Samsor aquifer properties, southeast Iran. Geophysical Research Abstracts,. European Geosciences Union, 7, 01999, 2005.

26. LASHKARIPOUR G.R. An investigation of groundwater condition by geoelectrical resistivity method: a case study in Korin aquifer, southeast Iran. J Spat Hydrol 3, 1, 2003.

27. SAHU P.C., SAHOO H. Targeting groundwater in tribal dominated Bonai area of drought-prone Sundargarh District, Orissa, India. A combined geophysical and remote sensing approach. J Hum Ecol 20, 109, 2006.

28. MAHAR M.T., KHUHAWAR M.Y., JAHANGIR T.M., BALOCH M.A. Determination of arsenic contents in groundwater of District Rahim Yar Khan Southern Punjab, Pakistan. Arabian Journal of Geosciences, DOI 10.1007/ s12517-015-1979-0, 2015.

29. OKONKWO A.C., EZEH C.C. Aquifer hydraulics and delineation of groundwater quality zones using electrical resistivity method at Oduma and environs in Enugu State, Southeastern Nigeria. International Research Journal of Geology and Mining, 3 (1), 31, 2013.

30. SRINIVASAN K., POONGOTHAI S., CHIDAMBARAM S. Identification of Groundwater Potential Zone by Using GIS and Electrical Resistivity Techniques in and Around the Wellington Reservoir, Cuddalore District, Tamilnadu, India. European Scientific Journal 9 (17), 312, 2013.

31. MAILET R. The Fundamental Equations of Electrical Prospecting. Geophysics, 12 (4), 529, 1974.

32. HENRIET J.P. Direct Applications of Dar Zarrouk Parameters in Groundwater Surveys. Geophysical Prospecting, 24 (2), 344, 1976.

33. MUNNA G.M., KIBRIYA N., NURY A.H., ISLAM S., RAHMAN H. Spatial Distribution Analysis and Mapping of Groundwater Quality Parameters for the Sylhet City Corporation (SCC) Area Using GIS. Hydrology, 3 (1), 1, 2015. 
34. FARID H.U., BAKHSH A., AHMAD N., AHMAD A., MAHMOOD-KHAN Z. Delineating Site-specific management zones for precision agriculture. Journal of Agricultural Science, Page 1 of 14. CCambridge University Press 2015. doi:10.1017/S0021859615000143.

35. BAKHSH A., KANWAR R.S., MALONE R.W. Role of landscape and hydrologic attributes in developing and interpreting yield clusters. Geoderma, 140, 235, 2007.

36. TRAN B.Q., NGUYEN T.T. Assessment of the influence of interpolation techniques on the accuracy of digital elevation model.VNU Journal of Science, Earth Sciences 24, 176, 2008.

37. KUMAR V. AND REMADEVI. Kriging of Groundwater Levels - A Case Study. Journal of Spatial Hydrology, 6 (1), 81, 2006.

38. BERNARD J. Short note on the principles of geophysical methods for groundwater investigation.www. Terraplus. com, 2003.

39. OLADAPO M.I.,MOHAMMED M.Z., ADEOYE O.O., ADETOLA O.O. Geoelectric investigation of the Ondo State Housing Corporation Estate Ijapo Akure southwestern Nigeria J. Mining Geol., 40 (1), 41, 2004.

40. WAPDA. Report on soil salinity survey and research division.Vol.1, Water and Power Development Authority
(WAPDA)-Lahore. (Supplement to Revised Action Program for Irrigated Agriculture, Annexes for water quality, 1977.

41. DANIEL A., LOUIS O., EMMANUEL C., KINGSLEY O. Delineation of potential groundwater zones using geoelectrical sounding data at Awka in Anambra State, South-eastern Nigeria, European Journal of Biotechnology and Bioscience, 3 (1), 01, 2015.

42. ARSHAD M., AHMAD N., USMAN M. Simulating Seepage from Branch Canal under Crop, Land and Water Relationships. International Journal of Agriculture \& Biology, 11 (5), 529, 2009.

43. KANWAL S., GABRIEL H.F., MAHMOOD K., ALI R., HAIDAR A., TEHSEEN T. Lahore's Groundwater Depletion-A Review of the Aquifer Susceptibility to Degradation and its Consequences. Technical Journal, University of Engineering and Technology (UET) Taxila, Pakistan, 20 (I), 26, 2015.

44. RAHMAN A. A GIS based DRASTIC model for assessing groundwater vulnerability in shallow aquifer in Aligarh, India. Applied Geography, 28, 32, 2008.

45. GUANG L.X., YANG H.H., FA S.Q. The shallow groundwater pollution's assessment of west Liaohe plain (eastern). Journal of Chemical and Pharmaceutical Research, 5 (11), 290, 2013. 
